\title{
Effect of Anchor Borrowers Programe (ABP) on Profitability and Income of Beneficiary Rice Farmers in Kebbi State, Nigeria
}

\author{
Gona Ayuba ", Mahmud Abba, Ogolekwu Alhaji Isaiah, Maikasuwa Mohammed Abubakar, \\ Kaka Yahaya
}

Department of Agricultural Economics and Extension, Kebbi State University of Science and Technology, Aliero, Nigeria

Email address:

ayubagona@gmail.com (G. Ayuba)

${ }^{*}$ Corresponding author

\section{To cite this article:}

Gona Ayuba, Mahmud Abba, Ogolekwu Alhaji Isaiah, Maikasuwa Mohammed Abubakar, Kaka Yahaya. Effect of Anchor Borrowers Programe (ABP) on Profitability and Income of Beneficiary Rice Farmers in Kebbi State, Nigeria. International Journal of Sustainable Development Research. Vol. 6, No. 3, 2020, pp. 43-48. doi: 10.11648/j.ijsdr.20200603.11

Received: May 4, 2020; Accepted: June 11, 2020; Published: July 17, 2020

\begin{abstract}
The study examined the effect of Anchor Borrowers Programme on Profitability and Income of Anchor Borrowers Programme (ABP) beneficiary rice farmers in Kebbi State, Nigeria. A Multistage sampling technique was used to select 500 ABP beneficiary and non-beneficiary rice farmers each giving a sample size of 1000. A well- structured questionnaires were administered to ABP beneficiary and non-beneficiary rice farmers for data collection. Data were analyzed using Descriptive Statistics, Net Farm Income Analysis, Gini-Coefficient and Lorenz Curve. Net Farm Income analysis revealed that both ABP beneficiary and non-beneficiary rice farmers realized net returns of $\$ 150,827.62$ and $\$ 62,294.37$, respectively per hectare, suggesting that both farmers realized profit. However, rate of return on investment for the two categories of farmers revealed that for every N1.00 invested, ABP beneficiary rice farmers realized $\$ 2.04$ while the non-beneficiary rice farmers realized N1.45. The high gain among the ABP beneficiary rice farmers suggest that ABP enhances the profit of the beneficiary rice farmers. Results further revealed Gini-coefficient values of 0.4152 and 0.7012 for beneficiary and non-beneficiary rice farmers, respectively. The result showed that income was more evenly distributed among the beneficiary rice farmers, suggesting that $\mathrm{ABP}$ enhances the income of the beneficiary farmers when compared with the non-beneficiary farmers. It is recommended that since $\mathrm{ABP}$ enhances the profitability and income of the beneficiary rice farmers, the program should be pursued vigorously in other States in order to improve the living condition of farmers in Nigeria. It is recommended that policies should be tailored towards inclusion of more farmers to benefit from $\mathrm{ABP}$ intervention.
\end{abstract}

Keywords: Anchor Borrowers Programme, Profitability, Income, Rice Farmers

\section{Introduction}

Rice is a staple food for about 2.6 billion people in the world. It is also the most important staple food for large part of the world human population. It is the second highest worldwide production after maize [1]. Since a large portion of maize crops are grown for the purpose other than human consumption; rice is the most important grain with regard to human nutrition and calorie intake [2]. Rice provides more than one fifth of the calorie consumed worldwide by human species, though relatively lower in protein compared to other cereals, it contains a better balance of amino acids [3].
Nigeria is the leading consumer and largest producer of rice in Africa and simultaneously one of the largest rice importers in the world. Rice being an important food security crop, is an essential cash crop generating more income for Nigerian farmers than any other cash crop in the country. In 2008, Nigeria produced approximately 2 million metric tonnes of milled rice and imported roughly 3 million metric tonnes, including the estimated 800,000 metric tonnes that is suspected to enter the country illegally on an annual basis [4]. According to [2], over the past several decades rice has established itself as a preferred staple food in Nigeria. Once reserve for ceremonial occasions, rice has grown in 
importance as a component of Nigerian diets. An average Nigerian consumes about $24.8 \mathrm{~kg}$ of rice per year, representing 9 percent of the total calories intake [5]. The increase in consumption of rice has led to its demand far exceeding supply except policy measures are put in place to improve production.

The program thrust of the ABP is provision of farm inputs in kind and cash (for farm labour) to small holder farmers to boost production of these commodities, stabilize inputs supply to agro processors and address the country's negative balance of payments on food. At harvest, the Smallholder Farmer (SHF) supplies his/her produce to the Agro-processor (Anchor) who pays the cash equivalent to the farmer's account. The Programme evolved from the consultations with stakeholders comprising Federal Ministry of Agriculture \& Rural Development, State Governors, millers of agricultural produce, and smallholder farmers to boost agricultural production and non-oil exports in the face of unpredictable crude oil prices and its resultant effect on the revenue profile of Nigeria [6]. In order to boost agricultural production and non-oil exports in the face of unpredictable crude oil prices and its resultant effect on the revenue profile of Nigeria, the Central Bank of Nigeria (CBN) in line with its developmental function, established the "Anchor Borrowers' Programme" (ABP). The Programme which is intended to create a linkage between anchor companies involved in the processing and small holder farmers (SHFs) of the required key agricultural commodities.

Over the years Nigeria has been grappling with food insecurity and its attendant consequences leading to hunger, massive importation, social disorders among others. In order to overcome the challenges posed by food insecurity so many agricultural programs were introduced with the sole aim of boosting food production, and stemming the tide of food insecurity. According to [7], in an effort to solve the challenges facing the agricultural sector and help Nigeria overcome the problems of food insecurity through importation by over dependence on oil revenue, led to the launch of the Anchor Borrowers' Programme (ABP) on $17^{\text {th }}$ November, 2015. It involves the provision of farm inputs in kind and cash (for farm labour) to smallholder farmers (SHF) to boost the production of targeted crop commodities such as rice, wheat, sugarcane, soybean among others. At harvest, the SHF supply his/her produce to the agro-processor (referred to as the Anchor) who pays the cash equivalent to the farmer's account.

Despite the prospects and high hope that greeted the launch of the ABP, with the hope that the program is targeted to alleviate poverty, increase income by enhancing the profit of the beneficiary farmers, an empirical study of the effect of
ABP on profitability and income of the beneficiary rice farmers has not been documented in Kebbi State. It is against this backdrop that this study hopes to find answers to the following research questions.

i. How profitable are the ABP beneficiary and nonbeneficiary rice farms?

ii. What is the income inequality among ABP beneficiary and non-beneficiary rice farmers?

iii. What are the constraints encountered in accessing incentives among ABP beneficiary rice farmers.

\section{Methodology}

\subsection{Study Area}

The study was conducted in Kebbi State, Nigeria. The choice of Kebbi State was premised on the fact that it is the State where the ABP was first launched in Nigeria. Kebbi State is located in the north-western part of Nigeria and occupies a land area of about 36,229 square kilometers with a population of about 3,630,931 [8]. Projecting this population to 2018 to be increasing at an annual population growth rate of $2.38 \%$, the state has an estimated population of about $4,938,066$ people. The State lies between latitudes $10^{\circ} 05^{1}$ and $13^{\circ} 27^{1} \mathrm{~N}$ of the equator and between longitudes $3^{\circ} 35^{1}$ and $6^{\circ} 03^{1} \mathrm{E}$ of the Greenwich. This area is characteristic of Sudan savannah sub-ecological zone with distinct wet and dry seasons. Soils are ferruginous on sandy parent materials evolving from sedentary weathering of sandstones.

Over two- third of the population are engaged in agricultural production, mainly arable crop alongside cash crops with animal husbandry. The major crops cultivated include sorghum, millet, maize, cowpea, sweet potato, rice, vegetables and fruits. Cash crops grown here include soybeans, wheat, ginger, sugarcane, tobacco and gum-arabic.

\subsection{Sampling Procedure and Sample Size}

Multistage sampling method was used to select the respondents for the study. First, the purposive selection of seven (7) Local Government areas (LGA) with the highest concentration of Anchor Borrowers Programme beneficiary farmers in the State. The LGAs are; Suru, Brinin-Kebbi, Bunza, Argungu, Augie, Dandi and Jega). Secondly, purposive selection of two villages/communities with the highest number of (ABP) beneficiary farmers from the seven (7) Local Government Areas giving a total of Fourteen (14) villages/communities. Thirdly, from each of the 14 villages /communities all together 500 beneficiary and non-beneficiary rice farmers each were proportionately selected randomly thus, giving a sample size of 1000 rice farmers for the study.

Table 1. Sampling Frame and the Sample Size of ABP Beneficiary Farmers in the State.

\begin{tabular}{llll}
\hline LOCAL GOVERNMENT AREAS & SAMPLING FRAME & VILLAGES /COMMUNITIES OF THE BENEFICIARIES & SAMPLE SIZE \\
\hline \multirow{2}{*}{ ARGUNGU } & 7,364 & Argungu & 74 \\
\multirow{2}{*}{ AUGIE } & Gulma & 54 \\
\hline
\end{tabular}




\begin{tabular}{llll}
\hline LOCAL GOVERNMENT AREAS & SAMPLING FRAME & VILLAGES /COMMUNITIES OF THE BENEFICIARIES & SAMPLE SIZE \\
\hline \multirow{2}{*}{ JEGA } & 3,020 & Jega & 30 \\
& & Basaura & 85 \\
BUNZA & 8,446 & Bunza & 109 \\
BIRNIN KEBBI & Raha & 115 \\
SURU & 10,909 & Makera & \\
& & Zauro & \\
DANDI & 11,549 & Suru & 33 \\
TOTAL & & Dakin Gari & 500 \\
\hline
\end{tabular}

Source: Kebbi State Anchor Borrowers Office, Birnin Kebbi, 2016.

\subsection{Analytical Technique}

\subsubsection{Model for Net Farm Income Analysis}

Net Farm Income Analysis is given by;

$$
\mathrm{NFI}=\mathrm{TR}-\mathrm{TC}
$$

Where:

NFI=Net Farm Income
TR=Total Revenue
TC $=$ Total Cost
TC $=$ TVC + TFC

$$
\mathrm{NFI}=\mathrm{TR}-\mathrm{TVC}-\mathrm{TFC}
$$

Rate of return $=$ Total Revenue $/$ Total Cost

\subsubsection{Gini Coefficient Model}

The Gini coefficient was employed to ascertain the pattern of income distribution among the ABP beneficiary and nonbeneficiary rice farmers. The Gini coefficient is a measure of inequality among values of a frequency distribution, for example, levels of income, wealth etc. It has values ranging from 0 to 1 . A Gini coefficient of zero (0) expresses perfect equality where all values are the same i.e. everyone has exactly equal income, while a Gini coefficient of one (1) (100 on the percentiles scale) expresses maximal inequality among values, for example where only one person has all the income. Therefore, a low Gini coefficient indicates a more equal distribution of income or wealth with 0 corresponding to complete equality while higher Gini coefficient indicates more unequal distribution with 1 corresponding to complete inequality.

The Gini coefficient $(\mathrm{G})$ is given as

$$
\mathrm{G}=1-\sum x y
$$

Where;

$\mathrm{G}=$ value of the Gini coefficient

$\mathrm{X}=$ percentage of farmers

$\mathrm{Y}=$ cumulative percentage of the farmers income

$\sum=$ summation sign

The $G$ has a possibility of values ranging from 0 to 1 , expressing the extent to which the farmers' income is either evenly or unevenly distributed.

\section{Results and Discussion}

\subsection{Cost and Returns Among ABP Beneficiary and Non-Beneficiary Farmers}

The results in Table 2 shows the costs and returns associated with rice production among ABP beneficiary and non-beneficiary rice farmers. The estimated total variable cost (TVC) amounted to $¥ 134,204.60$ for beneficiary and $\$ 125,049.49$ for non-beneficiary rice farmers. Total cost (TC) for beneficiary rice farmers was $\$ 145,192.38$ and $¥ 138,468.93$ for non-beneficiary rice farmers.

Table 2. Costs and Returns among ABP beneficiary and non-beneficiary per hectare.

\begin{tabular}{lll}
\hline Variable inputs & $\begin{array}{l}\text { Beneficiary } \\
\text { Cost (N) }\end{array}$ & $\begin{array}{l}\text { Non-beneficiary } \\
\text { Cost (N) }\end{array}$ \\
\hline Seed (kg) & 9203.67 & 8174.79 \\
Labour (man-day) & 69164.33 & 88438.88 \\
Fertilizer (kg) & 30589.38 & 15032.46 \\
Herbicides & 15417.43 & 6531.26 \\
Transportation cost & 4969.54 & 3050.00 \\
Empty bags & 4860.25 & 3822.10 \\
Total Variable Cost & $134,204.60$ & $125,049.49$ \\
Land Rent & 8963.93 & 9903.39 \\
Depreciation on fixed item capital & 2023.85 & 3516.05 \\
Total Fixed Cost & 10987.78 & 13419.44 \\
Total Cost & $145,192.38$ & $138,468.93$ \\
Revenue (N/ha) & 296020.00 & $200,763.30$ \\
Net Farm Income & 150827.62 & $62,294.37$ \\
Rate of Return on Investment & 2.04 & 1.45 \\
\hline
\end{tabular}

Source: Field Survey, 2018.

The estimated value of gross returns for beneficiary and non-beneficiary rice farmers were $\$ 296,020.00$ and $\$ 200,763.30$ respectively. Net Farm Income was $\$ 150,827 /$ hectare for ABP beneficiary and $\$ 62,294.37 /$ hectare for non-beneficiary rice farmers, which implies that farm production among beneficiary and nonbeneficiary rice farmers are both profitable in the study area. However, the beneficiaries realized more profit than the nonbeneficiaries suggesting that ABP enhances the profit of the beneficiary rice farmers. This result is in support of the 
findings of [9] who found that farmers with access to Agricultural credit interventions were more profitable than the non-beneficiaries. Average rate of return obtained were $\$ 2.04$ and $\$ 1.45$ for ABP beneficiary and non-beneficiary rice farmers, respectively. This implied that for every $\$ 1.0$ invested by $\mathrm{ABP}$ beneficiary rice farmers there was a return of $\$ 2.04$ while for the non-beneficiary rice farmers, for every $\$ 1.0$ invested there was a return of $\$ 1.45$. The high profit among beneficiary rice farmers could be attributed to the effect of ABP on rice farmers in the study area. This is in consonance with Studies by [10] and [11], in their various studies on profitability of rain fed and upland rice production system in Sokoto and Ogun States, Nigeria.

\subsection{Income Inequality of ABP Beneficiary and Non- Beneficiary Rice Farmers}

The Gini coefficient was used to ascertain the pattern of income distribution amongst the ABP beneficiary and nonbeneficiary rice farmers. The Gini coefficient is a measure of inequality among values of a frequency distribution. Results of income distribution among ABP beneficiary and nonbeneficiary rice farmers are presented in Tables 3 and 4.

Table 3. Distribution of income of ABP Non-beneficiary rice farmers in Kebbi State.

\begin{tabular}{|c|c|c|c|c|c|c|c|}
\hline $\begin{array}{l}\text { Range of income for } \\
\text { Non-beneficiary }\end{array}$ & Midpoint & $\begin{array}{l}\text { Frequency of } \\
\text { farmers }\end{array}$ & $\begin{array}{l}\text { Percentage of } \\
\text { farmer }(\mathrm{X})\end{array}$ & $\begin{array}{l}\text { Cumulative\% } \\
\text { of farmers }\end{array}$ & $\begin{array}{l}\text { Percentage of } \\
\text { income }\end{array}$ & $\begin{array}{l}\text { Cumulative\% } \\
\text { of income (Y) }\end{array}$ & $\mathbf{X Y}$ \\
\hline$<150,000$ & $89,780.00$ & 31 & 06.20 & 06.20 & 02.52 & 02.52 & 0.0010 \\
\hline $151,000-200,000$ & $197,033.33$ & 45 & 09.00 & 15.20 & 05.54 & 08.06 & 0.0072 \\
\hline $201,000-250,000$ & $126,933.36$ & 74 & 14.80 & 30.00 & 03.57 & 11.63 & 0.0172 \\
\hline $251,000-300,000$ & $269,983.07$ & 56 & 11.20 & 41.20 & 07.59 & 19.22 & 0.0215 \\
\hline $301,000-350,000$ & $349,883.33$ & 61 & 12.20 & 53.40 & 09.84 & 29.06 & 0.0354 \\
\hline $351,000-400,000$ & $369,470.83$ & 51 & 10.20 & 63.60 & 10.39 & 39.45 & 0.0402 \\
\hline $451,000-500,000$ & $496,200.00$ & 50 & 10.00 & 83.40 & 13.96 & 65.58 & 0.0655 \\
\hline $501,000-550,000$ & $534,385.00$ & 23 & 04.60 & 88.00 & 15.03 & 80.61 & 0.0370 \\
\hline 551,000 and above & $689,449.99$ & 60 & 12.00 & 100.00 & 19.39 & 100.00 & 0.0232 \\
\hline Total & $3,555,677.26$ & 500 & 100.00 & & 100.00 & & 0.2987 \\
\hline
\end{tabular}

Source: Field survey, 2018.

$\mathrm{G}=1-\sum \mathrm{xy}$.

$\mathrm{G}=1-0.2987$.

$\mathrm{G}=0.7013$.

Table 4. Distribution of income of ABP beneficiary rice farmers in Kebbi State.

\begin{tabular}{|c|c|c|c|c|c|c|c|}
\hline $\begin{array}{l}\text { Range of income for } \\
\text { Beneficiary farmers }\end{array}$ & Midpoint & $\begin{array}{l}\text { Frequency of } \\
\text { farmer }\end{array}$ & $\begin{array}{l}\text { Percentage of } \\
\text { farmers (X) }\end{array}$ & $\begin{array}{l}\text { Cumulative \% of } \\
\text { farmers }\end{array}$ & $\begin{array}{l}\text { Percentage of } \\
\text { income }\end{array}$ & $\begin{array}{l}\text { Cumulative\% } \\
\text { of income (Y) }\end{array}$ & $\mathbf{X Y}$ \\
\hline$<150,000$ & 70,825 & 72 & 14.40 & 14.40 & 02.97 & 02.97 & 0.0042 \\
\hline $151,000-200,000$ & $190,606.25$ & 90 & 18.00 & 32.00 & 08.00 & 10.97 & 0.0197 \\
\hline $201,000-250,000$ & $221,616.67$ & 74 & 14.80 & 47.20 & 09.30 & 20.27 & 0.0300 \\
\hline $251,000-300,000$ & 246,150 & 104 & 20.80 & 68.00 & 10.32 & 30.59 & 0.0636 \\
\hline $301,000-350,000$ & 327,600 & 59 & 11.80 & 79.80 & 13.73 & 44.32 & 0.0522 \\
\hline $351,000-400,000$ & 389,250 & 50 & 10.00 & 89.00 & 16.32 & 60.64 & 0.0606 \\
\hline 451,000 and above & $496,816.67$ & 09 & 01.80 & 100.00 & 20.83 & 100.00 & 0.0180 \\
\hline Total & $2,384,814.59$ & 500 & 100.00 & & 100.00 & & 0.5848 \\
\hline
\end{tabular}

Source: Field survey, 2018.

$\mathrm{G}=1-\sum \mathrm{xy}$.

$\mathrm{G}=1-0.5844$.

$\mathrm{G}=0.4156$.

Result in Table 3 revealed the Gini coefficient value for Non-beneficiary rice farmers as 0.7013 . This value indicates a wider income inequality among non-beneficiaries, implying that the income was not evenly distributed. This indicates high disparity in income among the study population and that large percentage are poor. Similarly, results in Table 5 reveals that the Gini coefficient value for ABP beneficiaries was 0.4156 . This value indicates a less income inequality or more equality in the distribution of income among $\mathrm{ABP}$ beneficiaries, implying that the income was evenly and equally distributed. This indicates low disparity in income among the study population and that there was no wide variation in income among the ABP beneficiary rice farmers in the study area. Based on results in Tables 4 and 5, the Gini coefficient values of 0.4156 and 0.7013 for ABP beneficiary and non-beneficiary rice farmers, respectively has shown that income among ABP beneficiaries was more evenly/equally distributed than among non-beneficiary rice farmers whose income was unevenly distributed indicating a wide inequality. This suggests that ABP scheme enhances the income of the beneficiary rice farmers. This result is in line with studies by $[12,13]$, who found out that income of the farmers had a positive and significant relationship with animal traction technology usage. 


\subsection{Constraints Encountered in Accessing ABP Intervention}

Table 5 reveals constraints encountered by the Anchor Borrowers' Programme beneficiary farmers in accessing ABP intervention/incentives.

Table 5. Distribution of $A B P$ beneficiary rice farmers according to constraints encountered in accessing ABP Intervention.

\begin{tabular}{lll}
\hline - & *Frequency & Percentage \\
\hline So many bureaucratic procedures & 487 & 97.4 \\
Non-timely release of inputs & 462 & 92.4 \\
Incentives not adequate & 449 & 89.8 \\
Quantity of fertilizer is inadequate & 431 & 86.2 \\
Opening of bank account is tedious & 318 & 63.6 \\
Certified seed is very expensive & 203 & 40.6 \\
One has to be close to a popular politician & 198 & 39.6 \\
\hline
\end{tabular}

Source: Field Survey, 2018.

*Multiple responses were recorded.

The results from the study in Table 5 revealed that the major challenge ABP beneficiary farmers faced in acquiring ABP intervention is the bureaucratic procedures that are involved which has the highest percentage of 487 (97.4\%). The result is in consonance with studies by [14] who reported that cumbersome protocol is the major constraint to accessing farm credits in Bauchi Metropolis, Nigeria and [15] whose study revealed that complex credit procedure is the major constraint affecting access to credit in their study on factors influencing credit demand by farmers in in Bokkos Local Government of Plateau State, Nigeria. However, the study is in disagreement with the findings of [16], whose investigation revealed that compulsory savings with the banks and high interest charged by the bank are the major problems encountered in accessing credit facility for women agricultural entrepreneurs in Gombe Microfinance Bank, Gombe Metropolis, Nigeria. The Table also reveals that delay in release of inputs to farmers is the next major challenge that ABP beneficiary rice farmers faced which has a percentage of $(92.4 \%)$. It further revealed that $(89.8 \%)$ number of respondents encountered the challenge of inadequate incentives given to them. Results from Table 5 further revealed that other constraints $A B P$ beneficiary farmers faced in ABP loan acquisition include; small quantity of fertilizer giving to them which has a percentage of $(86.2 \%)$. Opening of account by the ABP beneficiary is tedious is another challenge faced with a percentage of $(63.6 \%)$. Thus, it is also shown in Table 5 that the respondents (ABP beneficiary) were faced with the issue of certified seed been very costly. This was revealed by $40.6 \%$ of the ABP F beneficiary farmers.

\section{Conclusion}

Results from the study revealed that both categories of farmers realized a profit of $\$ 150,827.62$ and $\$ 62,294.37$ per hectare, respectively. However, the beneficiary farmers realized more profit than the non-beneficiary farmers, suggesting that ABP enhances the profitability of the beneficiary rice farmers. The study further revealed Gini Coefficient values of 0.4156 and 0.7013 for ABP beneficiary and non-beneficiary rice farmers, respectively. This indicates that income was more evenly distributed among ABP beneficiary rice farmers than the non-beneficiary rice farmers, suggesting that $\mathrm{ABP}$ enhances the income of the beneficiary rice farmers.

\section{Recommendation}

Based on the findings of the study, it is recommended that since Anchor Borrowers Programme enhances the profitability and Income of the Beneficiary rice farmers, the policy thrust should be structured towards inclusion of other farmers to benefit from the programme. The Programme should also be pursued vigorously in other States in order to enhance food productivity in the entire country, Nigeria.

\section{References}

[1] Food and Agriculture Organization Statistics, FAOSTAT, (2017). World Wheat, Corn and Rice. Retrieved on 26/12/2017 From: http://www.nue.okstate.edu/crop_information /world _wheat_production.htm.

[2] Usman, A. (2011). Analysis of Technical Efficiency and Its Determinants among Small Scale Rice Farmers in Niger State. Unpublished MSc. Dissertation. Department of Agricultural Economics and Rural Sociology, Ahmadu Bello University, Zaria, Nigeria.

[3] Oyewole, S. O. and E. S. Ebukiba (2010). Analysis of Technical Efficiency and its Determinants among Small Scale Rice Farmers in Lafia Local Government Area of Nasarawa State, Nigeria. Agriculture and Biology Journal of North America.

[4] National Bureau of Statistics (2013) Annual Abstract of Statistics 2007. Federal Republic of Nigeria, Abuja. Retrieve https://nigerianstat.gov.ng/elibrary.

[5] Food and Agriculture Organization (FAO) (2001). Rice Statistics. Website http://www.Riceweb.org.

[6] Bank of Agriculture (BOA) (2016): The Anchor Borrowers' Programme: Implementation for Sustainability. Paper Presented at the Central Bank of Nigeria, Development Finance Department Workshop, October, 12-13.

[7] Evbuomwan, G. O. and Okoye, L. U. (2017). Agricultural Value Chain Financing and Small Scale Farmers in Nigeria: The Pre-requisites. Proceedings of the $10^{\text {th }}$ Africa Farm Management Association Conference Held in Mauritius, from 20-24 November.

[8] National Population Commission (NPC) (2006). Population figure. Federal Republic of Nigeria, Abuja. Retrieval from https://www.npc.gov.ng.

[9] Bashir, M. and Gona, A. (2014). Effect of Bank of Agricultures' Micro Credit on Resource Productivity of Crop Farmers in Kebbi State, Nigeria. Equity Journal of Science and Technology, 2 (1): 74-80. 
[10] Yusuf, M. (2013) Resource Productivity, Profitability and Determinants of Technical Efficiency in Rain fed Lowland Rice Production System in Sokoto State, Nigeria. A PhD Pre defense Seminar Paper Presented to the Department of Agricultural Economics and Extension, Usmanu Danfodio University, Sokoto. 83pp.

[11] Idowu, A. O., Akerela, I. and O. Ezekiel (2009). Profitability Level of Upland Rice Production in Ilaro Agricultural Zone of Ogun State, Nigeria. Proceedings of the $23^{\text {rd }}$ Annual Conference of the Farm Management Association of Nigeria, Sokoto. Pp 317-322.

[12] Charles, A. A. (2003). Adoption of Animal Traction Technology in the Builsa District of upper East region of Ghana. Published M. Phil Thesis submitted to the Department of Agricultural Extension University of Ghana, Legon. http://ugspace.ug.edu.gh.

[13] Gona, A. and Mohammed, H. K (2019). Role of Animal Traction Technology on Profitability and Income of Small Scale Farmers in Kebbi State, Nigeria. International Journal of Current Research. Vol. 11 (8).
[14] Suleiman, A. A., Garba, M. and Mohammed, S. (2017). Constraints of Women's Access to Farm Credits in Bauchi Metropolis, Nigeria: An Impediment to Agripreneurship Development. Proceedings of the $31^{\text {st }}$ Annual Conference of Farm Management Association of Nigeria, Bauchi 2017. Pp 780-785.

[15] Onuwa, G. C., Yitnoe, G., Babatope, O. I. and Chizea, C. I. (2017). Analysis of Factors Influencing Agricultural Credit Demand by Farmers in Bokkos Local Government of Plateau State, Nigeria. Proceedings of the $31^{\text {st }}$ Annual Conference of Farm Management Association of Nigeria, Bauchi 2017. Pp 795-800.

[16] Sasa, S. A. and Umar, D. (2017). Determinants of Credit Facility for Women Agricultural Entrepreneurs in Gombe Microfinance Bank in Gombe Metropolis, Gombe State, Nigeria. Proceedings of the $31^{\text {st }}$ Annual Conference of Farm Management Association of Nigeria, Bauchi 2017. Pp 787794. 